\title{
IMPLEMETASI METODE AHP (ANALITYCAL HIERARCHY PROCESS) DALAM PENENTUAN TEMPAT WISATA AGRO (STUDI KASUS DI KECAMATAN PEGANTENAN, PAMEKASAN, MADURA)
}

\author{
Hoiriyah $^{1}$, Syaiful Bahri ${ }^{2}$ \\ ${ }^{1}$ Sistem Informasi, Fakultas Teknik, Universitas Islam Madura \\ ${ }^{2}$ Sistem Informasi, Fakultas Teknik, Universitas Islam Madura \\ 'hoiriyah.file.uim@gmail.com, ${ }^{2}$ ipoenkdewo@gmail.com
}

\begin{abstract}
ABSTRAK
Penggunaan sistem penunjang keputusan pada saat ini sudah semakin banyak digunakan tidak hanya saja oleh para pakar pengambil keputusan tetapi juga oleh masyarakat dalam penentuan pilihan terhadap suatu hal. Mengunjungi tempat wisata bagi masyarakat sekarang telah menjadi sebuah kebutuhan. Informasi yang relevan dan akurat tentang tempat wisata perlu disajikan lebih interaktif, agar pengguna informasi merasa terbantu. Karena itu dibutuhkan sebuah metode untuk dapat menyajikan informasi yang disampaikan, karena itu data diolah menggunakan metode sistem penunjang keputusan yang memberikan layanan interaksi dengan pengguna dengan menentukan nilai bobot kepentingan untuk setiap kriteria. Model pendukung keputusan ini akan menguraikan masalah multi faktor atau multi kriteria yang kompleks menjadi suatu hirarki. Beberapa kriteria penunjang keputusan antara lain Ketersediaan sumber daya dan daya tarik wisata, Fasilitas pariwisata dan fasilitas umum, Aksesebilitas, Kesiapan dan Keterlibatan masyarakat, dan Posisi strategis pariwisata. Berdasarkan nilai yang telah diberikan pada kriteria dan alternatif maka didapat hasil bahwa nilai Desa Plakpak mendapatkan rangking pertama dengan persentase $11.2 \%$, ditingkat kedua yaitu Desa Tebul Timur dengan persentase $10.4 \%$, diperingkat tiga Desa Tlagah $10.3 \%$, maka Desa terbaik adalah Desa Plakpak.
\end{abstract}

Kata Kunci: Sistem Pendukung Keputusan (SPK), Wisata Agro, Analitycal Hierarchy Process (AHP).

\begin{abstract}
The use of support systems at this time is increasingly plural can only be done by the expert results of the decision but also by the community in pricing. Finding the right place to be needs. Relevant and accurate information about tourist attractions needs to be presented more interactive, so that information users find it helpful. Therefore, a method is needed to be able to present the information submitted, therefore the data is processed using a method of supporting system that provides services with the user to determine the value for each criterion. The method used in determining the information presented is Analitycal Hierarchy Process $(A H P)$. AHP developed a model of decision support system (SPK) developed by Thomas L. Saaty. The supporting steps of this model will describe the complex multi-factor or multi-criteria problem created by the hierarchy. Some things that can be done include resources and tourist attraction, public facilities and public facilities, Accessibility, Readiness and community economy, and for tourism Based on the values that have been given to the criteria and alternatives, the results obtained that the value of the Village Plakpak get the first rank with a percentage of $11.2 \%$, the second level is Tebul Timur Village with a percentage of 10.4\%, ranked third in the Village Tlagah 10.3\%, the best village is Plakpak Village.
\end{abstract}

Keyword(s): Decision Support System (DSS), Tourism, Analitycal Hierarchy Process (AHP).

\section{PENDAHULUAN}

Pembangunan kepariwisataan perlu terus diupayakan guna menjadi sub sektor yang dapat meningkatkan perekonomian nasional dan daerah. Pariwisata sebagai industri jasa, menjadi pendorong utama perekonomian dunia sehingga banyak negara berusaha menjadikan negerinya sebagai objek yang kaya akan daya tarik kepariwisataan. Meningkatnya perkembangan teknologi informasi telah mengharuskan industri pariwisata serta berbagai industri lainnya untuk menerapkannya. Seiring pesatnya perkembangan teknologi tersebut membuka peluang untuk mempromosikan daerah wisata yang dapat dioptimalkan. Secara umum teknologi informasi akan sangat bermanfaat 
dalam penyajian informasi yang cepat, mudah dan akurat yang sangat dibutuhkan oleh wisatawan. Salah satu dari sekian banyak teknologi informasi yang bermanfaat bagi wisatawan dan dapat diakses dengan mudah dari manapun adalah internet. (Palit, Talumingan and Rumagit, 2017)[4].

Saat ini perkembangan teknologi informasi sudah sedemikian pesat tidak hanya teknologi perangkat keras dan perangkat lunak saja, tetapi metode komputasi juga ikut berkembang. Salah satu metode komputasi yang cukup berkembang saat ini adalah metode sistem pengambilan keputusan (Decisions Support System). Dalam teknologi informasi, sistem pengambilan keputusan merupakan cabang ilmu yang letaknya diantara sistem informasi dan sistem cerdas. Proses pengambilan keputusan dari berbagai alternatif yang ada maka dibutuhkan adanya suatu kriteria. Setiap kriteria harus mampu menjawab satu pertanyaan penting mengenai seberapa baik suatu alternatif dapat memecahkan suatu masalah yang dihadapi. Salah satu permasalahan pengambilan keputusan yang dihadapkan pada berbagai kriteria adalah proses pemilihan obyek wisata. Banyak metode yang dapat digunakan dalam sistem pengambilan keputusan. Salah satu metode tersebut yang digunakan dalam penelitian ini adalah metode Analytical Hierarchy Process (AHP). Konsep metode AHP adalah merubah nilai-nilai kualitatif menjadi nilai kuantitatif, (Ranius, 2015)[5].

Untuk mempermudah calon wisatawan dalam mengetahui lebih banyak mengenai tempat wisata dengan informasi yang akurat dan rekomendasi pemilihan objek wisata yang sesuai dengan kriteria-kriteria yang dipilih, maka dibutuhkan sebuah sistem komputerisasi yang memuat seluruh informasi daerah wisata secara online, dengan metode sistem pendukung keputusan Penentuan Tempat Wisata Agro di Kecamatan Pegantenan Dengan metode AHP (Analytic Hirearchy Process) diharapkan dapat digunakan untuk mendapatkan informasi dan pendukung keputusan pemilihan objek wisata secara efektif.

\section{A. Kajian Pustaka}

(Ranius, 2015), telah membuat penelitian tentang Sistem Pendukung Keputusan (SPK) sistem pendukung keputusan penentuan tempat tujuan wisata unggulan di kota palembang dengan mengunakan metode AHP. , Aplikasi yang dibuat merupakan sistem yang dikemas untuk menentukan tempat tujuan wisata unggulan sehingga dapat memberikan masukan untuk mengetahui wisata yang dijadikan detinasi unggulan. Kota Palembang merupakan diantara kota tertua di Indonesia berumur setidaknya 1382 tahun jika berdasarkan prasasti Sriwijaya yang dikenal sebagai prasasti Kedudukan Bukit. Menurut Prasasti tersebut tahun 16 Juni. Pada saat itu oleh penguasa Sriwijaya didirikan Wanua yang sekarang dikenal sebagai kota Palembang. Palembang merupakan kota terbesar kedua di Pulau Sumatera. Selain terkenal dengan pempeknya, Palembang juga mempunyai potensi wisata yang tidak kalah dengan kota lainnya di Sumatera. AHP merupakan suatu model sistem pendukung keputusan (SPK) yang dikembangkan oleh Thomas L. Saaty. Model pendukung keputusan ini akan menguraikan masalah multi faktor atau multi kriteria yang kompleks menjadi suatu hirarki.

Dahriani Tanjung, 2015, telah membuat penelitian tentang pemilihan objek wisata di sumatera utara dengan metode analytical hierarchy process (ahp), dalam menyelesaikan persoalan dengan menggunakan sistem perangkingan berdasarkan bobot global. Dengan adanya Sistem Pendukung Keputusan untuk memilih objek wisata dengan menggunakan metode Analitic Hierarchy Process (AHP) dan pengujian sistem dengan menggunakan software Super Decisions diharapkan dapat membantu pengunjung dalam pemilihan objek wisata dan dapat menghasilkan suatu hasil optimal yang memenuhi rasa kepuasan yang tinggi bagi pengunjung objek wisata. Dari hasil uji coba yang dilakukan dengan Tools Super Decisions diperoleh model keputusan dengan prioritas yaitu untuk seluruh bobot/prioritas kriteria dan alternatif [7].

(Bintoro et al., 2018), telah membuat penelitian tentang Sistem Penunjang Keputusan Tujuan Wisata Air Terjun di Kota Bogor Menggunakan Metode AHP Setiap wisatawan memiliki kriteria yang harus dipertimbangkan. Mulai dari biaya, jarak 
tempuh, luas area wisata, dan ketinggian curug dan fasilitas yang ditawarkan. Oleh karena itu diperlukan sistem penunjang keputusan untuk membantu wisatawan dalam mengambil keputusan menentukan air terjun yang akan dikunjungi. Adapun kriteria yang digunakan dalam penilaian wisata air terjun yaitu : Biaya, Jarak Tempuh, Fasilitas, Luas Area Wisata, dan Ketinggian Curug. Dimana setiap kriteria akan diberikan bobot. Pembobotan penilaian tersebut mencakup angka 1 samapi 5 dimana angka 5 adalah nilai terbesar.Sistem Penunjang Keputusan ini menggunakan metode Analytical Hierarchy Process (AHP), dengan Software Expert Choice 11. Dari hasil perhitungan AHP berdasarkan 5 kriteria dan 10 alternatif maka didapatkan tiga urutan nilai tertinggi yaitu Curug Nangka mendapatkan rangking pertama dengan persentase $16.7 \%$ [1],

\section{B. Landasan Teori}

\section{1) Sistem Pendukung Keputusan (SPK)}

Sistem Pendukung Keputusan biasa juga disebut dengan istilah DSS. Pada awal tahun 1970 ada seorang ahli mendefinisikan sistem pendukung keputusan merupakan sekumpulan prosedur berbasis model untuk data pemprosesan dan penilaian guna membantu para manajer mengambil keputusan. (Masruro and Luthfi, 2005)[3] Menurut Keen dan Scoot Morton Sistem Pendukung Keputusan merupakan penggabungan sumber-sumber kecerdasan individu dengan kemampuan komponen untuk memperbaiki kualitas keputusan. Sistem Pendukung Keputusan juga merupakan sistem informasi berbasis komputer untuk manajemen pengambilan keputusan yang menangani masalah - masalah semi struktur. (Busthomy et al., 2016)[2].

Sistem pendukung keputusanatau Decision Support System (DSS) adalah sistem informasi interaktif yang menyediakan informasi, pemodelan, dan pemanipulasian data yang digunakan untuk membantu pengambilan keputusan pada situasi yang semi terstruktur dan situasi yang tidak terstruktur dimana tak seorang pun tahu secara pasti bagaimana keputusan seharusnya dibuat. Konsep DSS dikemukakan pertama kali oleh Scoot Morton pada tahun 1971.(Rohandi, Tuloli and Jassin, 2017)[6]

\section{2) Analytical Hierarchy Process (AHP)}

Proses hierarki adalah suatu model yang memberikan kesempatan bagi perorangan atau kelompok untuk membangun gagasan-gagasan dan mendefinisikan persoalan dengan cara membuat asumsi mereka masing-masing dan memperoleh pemecahan yang diinginkan darinya. Ada dua alasan utama untuk menyatakan suatu tindakan akan lebih baik dibanding tindakan lain. AHP merupakan suatu model pendukung keputusan yang dikembangkan oleh Thomas L. Saaty. Model pendukung keputusan ini akan menguraikan masalah multi faktor atau multi kriteria yang kompleks menjadi suatu hirarki, menurut Saaty (1993), hirarki didefinisikan sebagai suatu representasi dari sebuah permasalahan yang kompleks dalam suatu struktur multi level dimana level pertama adalah tujuan, yang diikuti level faktor, kriteria, sub kriteria, dan seterusnya ke bawah hingga level terakhir dari alternatif. Dengan hirarki, suatu masalah yang kompleks dapat diuraikan ke dalam kelompokkelompoknya yang kemudian diatur menjadi suatu bentuk hirarki sehingga permasalahan akan tampak lebih terstruktur dan sistematis.

$A H P$ sering digunakan sebagai metode pemecahan masalah dibanding dengan metode yang lain karena alasan-alasan sebagai berikut :

1. Struktur yang berhirarki, sebagai konsekuesi dari kriteria yang dipilih, sampai pada subkriteria yang paling dalam.

2. Memperhitungkan validitas sampai dengan batas toleransi inkonsistensi berbagai kriteria dan alternatif yang dipilih oleh pengambil keputusan.

Memperhitungkan daya tahan output analisis sensitivitas pengambilan keputusan.

AHP didasarkan atas 3 prinsip dasar yaitu:

\section{Dekomposisi}

Dengan prinsip ini struktur masalah yang kompleks dibagi menjadi bagian-bagian secara hierarki. Tujuan didefinisikan dari yang umum sampai khusus. Dalam bentuk yang paling sederhana struktur akan dibandingkan tujuan, kriteria dan level alternatif. Tiap himpunan alternatif mungkin akan dibagi lebih jauh menjadi tingkatan yang lebih detail, mencakup lebih banyak kriteria yang lain. Level paling atas dari hirarki merupakan tujuan yang terdiri 
atas satu elemen. Level berikutnya mungkin mengandung beberapa elemen, di mana elemenelemen tersebut bisa dibandingkan, memiliki kepentingan yang hampir sama dan tidak memiliki perbedaan yang terlalu mencolok. Jika perbedaan terlalu besar harus dibuatkan level yang baru.

Bentuk struktur dekomposisi yakni :

Tingkat pertama: Tujuan keputusan (Goal)

Tingkat kedua : Kriteria - kriteria

Tingkat ketiga : Alternatif - alternatif

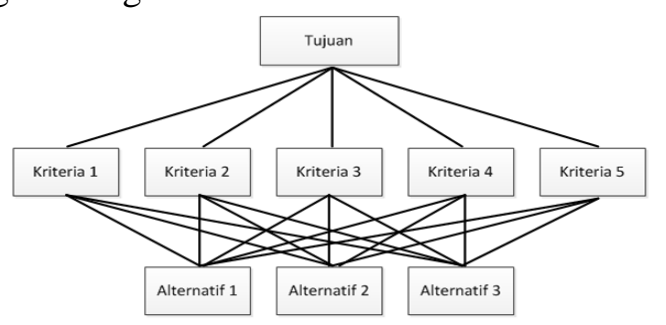

Gambar 1. Struktur Hierarki

(sumber:

jasaskripsisistempendukungkeputusan)

2. Perbandingan penilaian / pertimbangan (comparative judgments).

Dengan prinsip ini akan dibangun perbandingan berpasangan dari semua elemen yang ada dengan tujuan menghasilkan skala kepentingan relatif dari elemen. Penilaian menghasilkan skala penilaian yang berupa angka. Perbandingan berpasangan dalam bentuk matriks jika dikombinasikan akan menghasilkan prioritas.

\section{Sintesa Prioritas}

Sintesa prioritas dilakukan dengan mengalikan prioritas lokal dengan prioritas dari kriteria bersangkutan di level atasnya dan menambahkannya ke tiap elemen dalam level yang dipengaruhi kriteria. Hasilnya berupa gabungan atau dikenal dengan prioritas global yang kemudian digunakan untuk memboboti prioritas lokal dari elemen di level terendah sesuai dengan kriterianya.

\section{Logical Consistency}

Logical consistency merupakan karakteristik penting AHP. Hal ini dicapai dengan mengagresikan seluruh eigen vector yang diperoleh dari berbagai tingkatan hirarki dan selanjutnya diperoleh suatu vektor composite tertimbang yang menghasilkan urutan pengambilan keputusan.

3) Agro Wisata
Wisata Agro adalah aktivitas wisata yang melibatkan penggunaan lahan pertanian atau fasilitas terkait dan menjadi daya tarik bagi wisatawan. Agrowisata memiliki beragam variasi, seperti labirin jagung, wisata petik buah, memberi makan hewan ternak, hingga restoran di atas laut.

Agrowisata merupakan salah satu potensi dalam pengembangan industri wisata di seluruh dunia. Wesvarrdec (2010-02-18)

\section{METODE PENELITIAN}

Lokasi penelitian yang diambil oleh peneliti adalah Kecamatan Pegantenan yang beralokasi di jalan raya pasar Pegantenan Kabupaten Pamekasan.

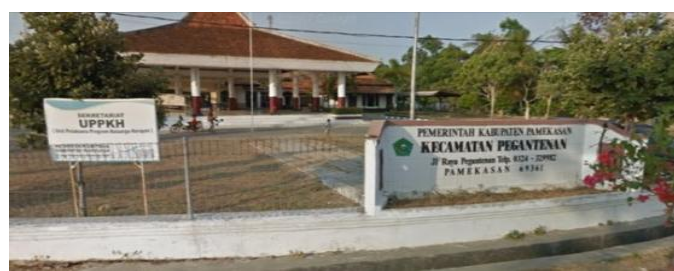

Gambar 2. Lokasi Penelitian

Data yang dikumpulkan adalah sebagai berikut:

1) Data primer, diperoleh dari responden melalui kuesioner dan wawancara.

2) Data sekunder, diperoleh dari studi literatur untuk mendukung data yang diperoleh dari hasil penyebaran kuisioner dan wawancara

\section{HASIL DAN PEMBAHASAN}

Sistem pendukung keputusan penentuan tempat wisata agro di kecamatan pegantenan faktor kriteria untuk penentuan tempat wisata agro, sekurang-kurangnya meliputi

1. Ketersediaan sumber daya dan daya tarik wisata;

2. Fasilitas pariwisata dan fasilitas umum;

3. Aksesebilitas;

4. Kesiapan dan Keterlibatan masyarakat;

5. Posisi strategis pariwisata dalam pembangunan daerah.

Dari faktor kriteria dan 5 intensitas pada masing-masing kriteria tersebut dilakukan penilaian pada masing-masing tempat tujuan dengan menggunakan model AHP sehingga didapatkan nilai total pada masing-masing tempat tujuan. Sehingga berdasarkan faktor kriteria dan intensitas-intensitas pada masingmasing kriteriatersebut urutan hirarkinya dapat digambarkan seperti pada gambar 2 , 


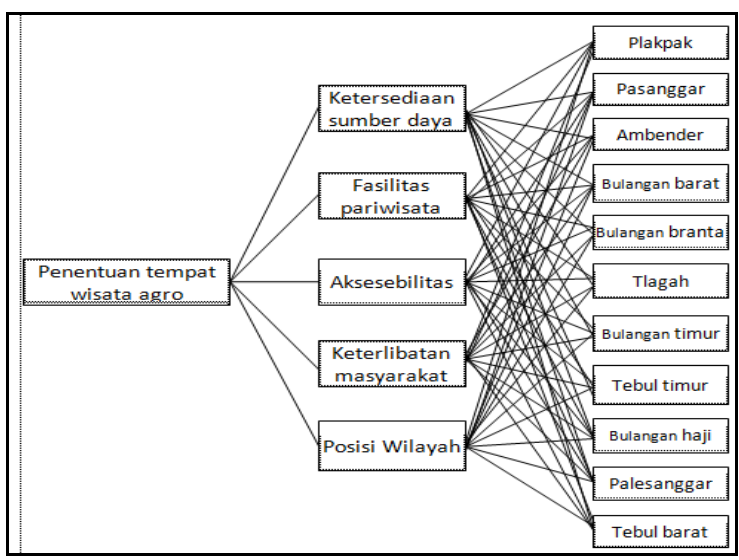

Gambar 3. Urutan Hirarki Sistem

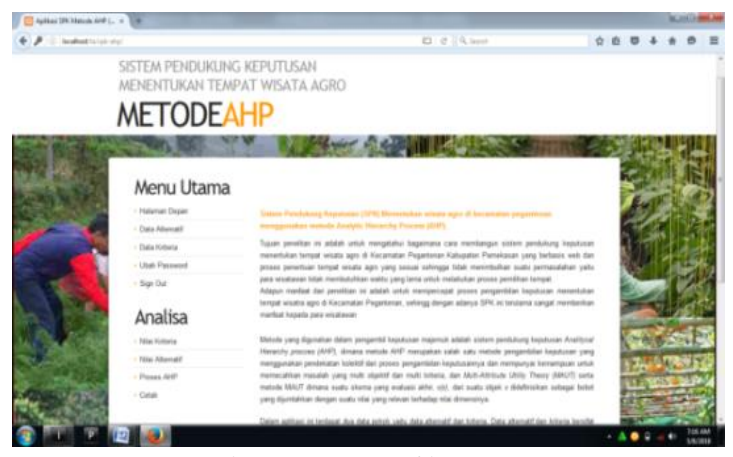

Gambar 4. Tampilan Utama

Gambar 3 diatas merupakan tampilan awal yang memiliki beberapa menu seperti input data alternatif, input data ktiteria, menu analisis dan cetak hasil.

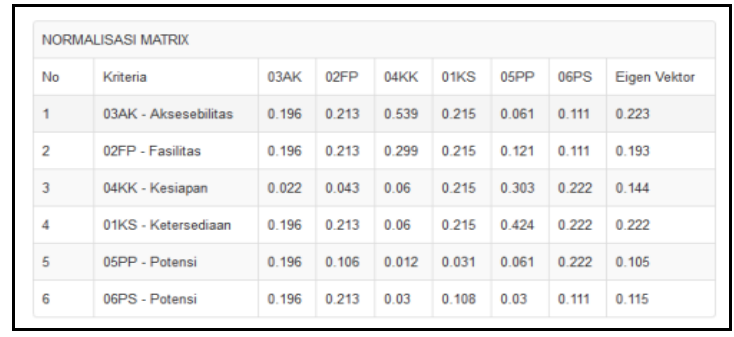

Gambar 5.Tampilan Nilai Perbandingan Kriteria

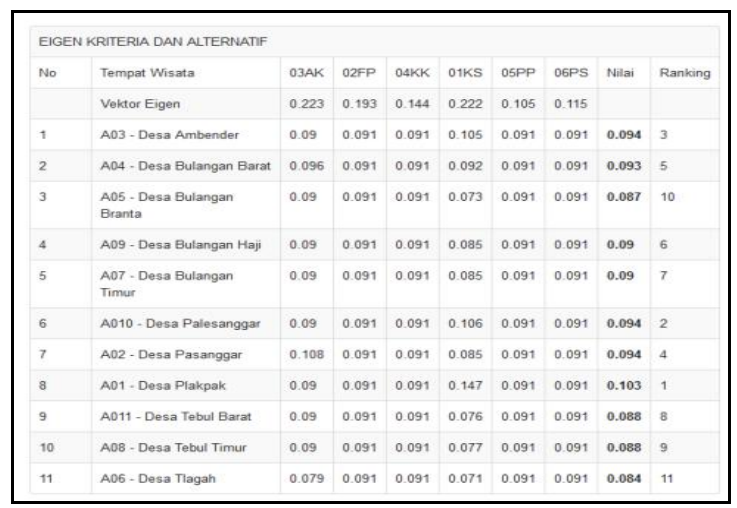

Gambar 6.Tampilan eagen kiteria dan alternatif

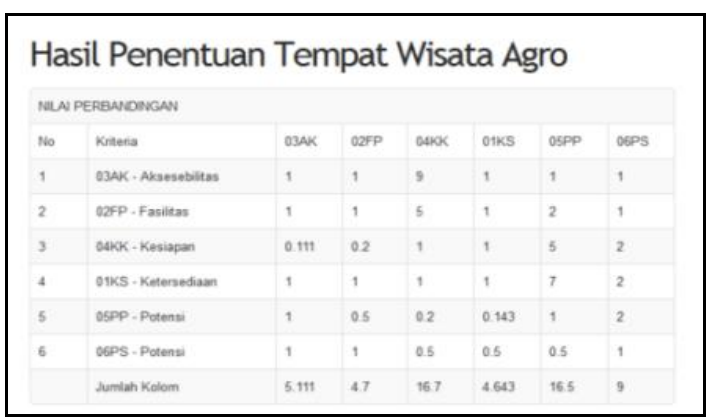

Gambar 7. Tampilan Nilai Perbandingan Kriteria

\section{A. Pengujian Konsistensi}

Untuk mendapatkan solusi yang baik,dperlukan kekonsistenan dalam mengisi bobot kriteria. Oleh karena itu Saaty mendefinisikan sebuah rasio konsistensi (CR) untuk memberikan toleransi kriteria matriks yang konsisten. Sebuah matriks dianggap konsisten jika nilai $\mathrm{CR}<0,1$ atau inkonsisten yang diperbolehkan hanya $10 \%$ saja, dapat dihitug dengan rumus :

$$
\begin{aligned}
& C R=C I / R I \\
& C I=\frac{\lambda \max -n}{n-1} \\
& C I=\frac{0,0442-5}{5-1} \\
& =1,24 \quad C R=\frac{1,24}{1.12}=1,10
\end{aligned}
$$

Tabel 1 Konsistensi

\begin{tabular}{|c|c|}
\hline $\begin{array}{c}\lambda \text { maks (lamda } \\
\text { maks) }\end{array}$ & $\begin{array}{c}\text { CI (konsistensi } \\
\text { Index) }\end{array}$ \\
\hline 0,0507 & $(1,24)$ \\
\hline $\begin{array}{c}\text { CR (konsistensi } \\
\text { Ratio) }\end{array}$ & $\begin{array}{c}\text { IR (Index Ratio) } \\
5 \text { kriteria }\end{array}$ \\
\hline$(1,10)$ & 1,12 \\
\hline
\end{tabular}

\section{B. Hasil Pengujian perhitungan Alternatif}

Tabel 2. Matrik perbandingan berpasangan alternatif untuk kriteria

\begin{tabular}{|c|c|c|c|c|c|c|c|}
\hline & K1 & K2 & K3 & K4 & \multirow{2}{*}{ K5 } & \multirow{2}{*}{ Bobot } & \\
\cline { 2 - 6 } & $\mathbf{0 , 3 0 4}$ & $\mathbf{0 , 3 1 1}$ & $\mathbf{0 , 1 2 7}$ & $\mathbf{0 , 1 8 4}$ & $\mathbf{0 , 0 7 4}$ & & \\
\hline A1 & 0,046 & 0,049 & 0,021 & 0,029 & 0,012 & $\mathbf{0 . 1 1 1}$ & 1,0000 \\
\hline A2 & 0,050 & 0,058 & 0,018 & 0,027 & 0,012 & $\mathbf{0 . 1 0 2}$ & 4,0000 \\
\hline A3 & 0,044 & 0,041 & 0,023 & 0,028 & 0,010 & $\mathbf{0 . 0 9 7}$ & 5,0000 \\
\hline A4 & 0,043 & 0,038 & 0,016 & 0,022 & 0,009 & $\mathbf{0 . 0 7 8}$ & 9,0000 \\
\hline A5 & 0,031 & 0,033 & 0,011 & 0,018 & 0,007 & $\mathbf{0 . 0 8 5}$ & 8,0000 \\
\hline A6 & 0,025 & 0,023 & 0,012 & 0,017 & 0,006 & $\mathbf{0 . 1 0 3}$ & 3,0000 \\
\hline A7 & 0,021 & 0,018 & 0,007 & 0,013 & 0,006 & $\mathbf{0 . 0 9 4}$ & 6,0000 \\
\hline A8 & 0,014 & 0,021 & 0,007 & 0,009 & 0,004 & $\mathbf{0 . 1 0 5}$ & 2,0000 \\
\hline A9 & 0,015 & 0,015 & 0,005 & 0,009 & 0,004 & $\mathbf{0 . 0 8 6}$ & 7,0000 \\
\hline A10 & 0,008 & 0,007 & 0,003 & 0,006 & 0,002 & $\mathbf{0 . 0 6 6}$ & 10,0000 \\
\hline A11 & 0,008 & 0,006 & 0,003 & 0,005 & 0,003 & $\mathbf{0 . 0 6 6}$ & 11,0000 \\
\hline
\end{tabular}




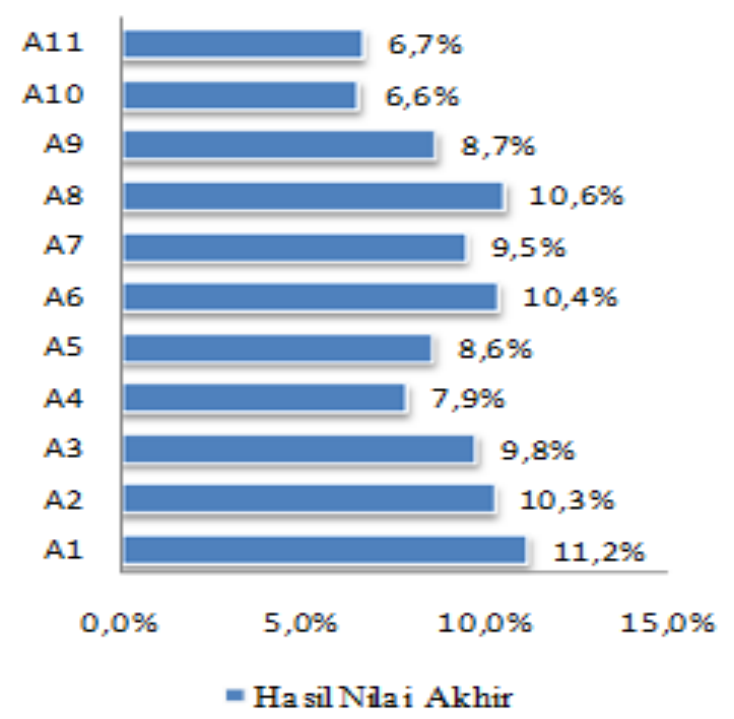

Gambar 8. Nilai akhir dalam persentasi

Berdasarkan gambar 7 dapat disimpulkan bahwa nilai Desa Plakpak mendapatkan rangking pertama dengan persentase $11.2 \%$, ditingkat kedua yaitu Desa Tebul Timur dengan persentase $10.4 \%$, diperingkat tiga Desa Tlagah $10.3 \%$. Dengan begitu desa Plakpak berpotensi menjadi pilihan untuk dijadikan tempat wisata agro.

\section{KESIMPULAN}

Metode AHP untuk proses pendukung keputusan Penentuan tempat wisata agro di Kecamatan Pegantenan yaitu menggunakan metode Analytic Hirearchy Process AHP dan didapatkan hasil sebagai berikut: Desa Plakpak mendapatkan rangking pertama dengan persentase $11.2 \%$, ditingkat kedua yaitu Desa Tebul Timur dengan persentase $10.4 \%$, diperingkat tiga Desa Tlagah $10.3 \%$, maka Desa Plakpak adalah Desa Plakpak

Hasil perhitungan yang dihasilkan dapat dijadikan sebagai rekomendasi yang dapat digunakan wisatawan untuk menentukan pilihan tempat wisata agro yang akan dituju.

\section{DAFTAR PUSTAKA}

[1] Bintoro, ketut B. Y. et al. (2018) 'Sistem Penunjang Keputusan Tujuan Wisata Air Terjun di Kota Bogor Menggunakan Metode AHP', SinkrOn; Vol 2 No 2 (2018): Call Paper Volume 2 Nomor 2 April 2018, 2(April 2018), pp. 164-171. Availableat:http://jurnal.polgan.ac.id/index .php/sinkron/article/view/114.

[2] Busthomy, A. et al. (2016) 'Sistem Pendukung Keputusan Untuk Pemilihan Objek Wisata Di Kabupaten Pasuruan Dengan Menggunakan Metode $A H P^{\prime}, 2(1)$, pp. 33-56.

[3] Masruro, A. and Luthfi, E. T. (2005) 'Sistem Penunjang Keputusan Penentuan Lokasi Wisata Menggunakan Ahp Abstraksi Pendahuluan Tinjauan DAFTAR PUSTAKA', 15(04), pp. 1-5.

[4] Palit, I. G., Talumingan, C. and Rumagit, G. A. J. (2017) 'Strategi Pengembangan Kawasan Agrowisata Rurukan metode AHP', Jurnal Agri-SosioEkonomi Unsrat, 13(2), pp. 21-34.

[5] Ranius, A. Y. (2015) 'Sistem pendukung keputusan penentuan destinasi wisata unggulan di kota palembang'.

[6] Rohandi, M., Tuloli, M. Y. and Jassin, M. R. T. (2017) 'Sistem Pendukung Keputusan dalam Penentuan Prioritas Pengembangan Kawasan Wisata Bawah Laut menggunakan AHP', 6(4), pp. 2-8.

[7] Tanjung, d. H. Et al. (2015) 'Pemilihan Objek Wisata Di Sumatera Utara Dengan Metode Analytical Hierarchy Process (ahp)', pp. 592-597. 